\title{
Estudio del pretratamiento hidrotermico para favorecer la actividad de las celulasas libres e inmovilizadas
}

\section{Study of hydrothermal pretreatment to increase the activity of free and immobilized cellulases.}

\author{
Annie Y. Vargas.; Laura Luque.;José J. Martinez
}

\begin{abstract}
Escuela de Ciencias Químicas. Facultad de Ciencias. Grupo de Catálisis (GC-UPTC). Universidad Pedagógica y Tecnológica de Colombia. Avenida Central del Norte, Tunja, Boyacá, Colombia. jose.martinez@uptc.edu.co
\end{abstract}

\section{Resumen}

Para mejorar la actividad enzimática de las celulasas es necesario disminuir las barreras estructurales de la celulosa con distintos pretratamientos, en este trabajo se realizó el estudio del pretratamiento hidrotérmico de celulosa comercial a distintos factores de severidad, con el fin de mejorar la conversión a azucares reductores y disminuir la cristalinidad. Además, se estudió la degradación enzimática de la celulosa pretratada hidrotermicamente con celulasas comerciales previamente inmovilizadas en $\mathrm{SiO}_{2}-\mathrm{NH}_{2}$. Los resultados indican una mayor degradación de la celulosa tratada frente a la celulosa no tratada, a pesar que la actividad enzimática disminuye cuando las enzimas se inmovilizan. Este proceso es un tratamiento amigable con el medio ambiente.

Palabras Clave: celulasas, pretratamiento hidrotérmico, factor de severidad

\begin{abstract}
It is necessary decrease the structural walls to improve the enzymatic activity of cellulases. In this work, the hydrothermal treatment of commercial celluloses using different severity factors was studied. The principal aim was increase the conversion at reductor sugars and decreases the crystallinity index. Besides, it was studied the enzymatic degradation using commercial cellulase and immovilized in $\mathrm{SiO}_{2}-\mathrm{NH}_{2}$ support. The results shown that a higher degradation with pretreated cellulose was
\end{abstract}


obtained compared with commercial cellulose. However, the activity is lower when the cellulases are immobilized. This process is treatment friendly with the environmental.

Keywords: celullases, hydrothermal pretreatment, severity factor

\section{Introducción}

La hidrólisis de la celulosa en azucares reductores es un paso crucial para el uso efectivo de la biomasa lignocelulósica, dado que pueden ser refinados de manera eficiente para la obtención de diversos productos químicos, biocombustibles, alimentos y medicinas, entre otros. La hidrólisis ácida tiene la desventaja de la conversión de los azúcares en productos de degradación como alquitranes, además presentan problemas asociados a residuos, corrosión y una ineficiente separación de los productos finales que hace a este tratamiento nada amigable con el ambiente (Zheng, Zhao, Fuqing, \& Yebo, 2014)(Huang \& Ragauskas, 2012). La degradación de los azúcares se puede prevenir mediante el uso de enzimas que favorecen la conversión selectiva de la celulosa en glucosa, además la hidrólisis enzimática en comparación con la hidrólisis ácida provee mayores ventajas ya que la hidrolisis se realiza normalmente a condiciones ( $\mathrm{pH} \mathrm{4,8)} \mathrm{y} \mathrm{temperaturas} \mathrm{suaves}(318-323 \mathrm{~K})$. Sin embargo, la hidrólisis enzimática de la lignocelulosa se ve obstaculizada por la cristalinidad de la celulosa, grado de polimerización de celulosa, área de superficie, y el contenido de lignina (Sun \& Jiayang, 2002)(Nickerson \& Habrle, 1947)(Li, Pu, Kumar, Ragauskas, \& Wyman, 2012). La celulosa se degrada enzimáticamente en glucosa por la acción sinérgica de tres clases distintas de enzimas Endoglucanasas (EC 3.2.1.4), Exoglucanasas (EC 3.2.1.91) y $\beta$-glucosidasas (EC 3.2.1.21).

Las endoglucanasas inician el proceso de hidrólisis de la celulosa, lo que altera los enlaces internos $\beta$-1,4-glucosídicos a lo largo de la cadena, aumentando el número de extremos de cadenas de celulosa disponibles para exoglucanasas para posterior hidrolisis de la celobiosas. Estas reacciones de hidrólisis predominan en las regiones amorfas de celulosa (Juturu \& Chuan, 2014). Una vez degradada las zonas amorfas, la región cristalina comienza a ser hidrolizada, como resultado de la acción sinergística de la endoglucanasa y la exoglucanasa. Finalmente, la $\beta$-glucosidasa (BG también conocidas glucohidrolasas: EC 3.2.1.21), hidroliza la celobiosa para producir glucosa. Esta última etapa, limita la degradación de la celulosa, dado que la celobiasa inhibe la acción de las glucanasas (Balat, 2011). 
El éxito de la hidrólisis enzimática depende del estrecho contacto entre las celulasas y la celulosa. Sin embargo, la enzima tiende a disociarse lo que resulta en su rápida inactivación, por ello, requiere ser inmovilizada para su aplicación industrial, permitiendo el reúso y conservando su actividad enzimática (Rojas, Martínez, \& Vargas, 2014). La inmovilización de celulasas presenta como ventajas el uso de cantidades muy bajas de esta, presentando alta actividad hidrolítica y la posibilidad de reutilización.

En consecuencia, pretratamientos que disminuyan las barreras estructurales y permitan una mejor acción de los tratamientos enzimáticos, deben realizarse. Sin embargo, muchos de estos pretratamientos también son corrosivos y costosos. El pretratamiento hidrotérmico es simple y ambientalmente más amigable dado que el agua a temperaturas superiores a la temperatura de ebullición se puede aplicar para la fragmentación en sus componentes mayoritarios de la celulosa (Dinjus \& Kruse, 2004; Nitsos, Matis, \& Triantafyllidis, 2013; Xiong, Pham, \& Datye, 2014). La búsqueda de tratamientos amigables en todos los procesos de la química es una necesidad apremiante (Moreno, Muñoz Prieto, \& Casanova, 2015)(Muñoz Prieto, Rivas, \& Sánchez, 2013)(Chaparro et al., 2015).

De esta manera, el principal reto es disminuir la estructura cristalina de la celulosa a bajas condiciones de temperatura, para el posterior tratamiento enzimático, teniendo en cuenta que se requiere aumentar la estabilidad de la enzima en el tratamiento de la hidrólisis de la celulosa. Así, en este trabajo se probaron diferentes tratamientos hidrotermicos de celulosa y se estudió la actividad enzimática de celulasas comerciales libres e inmovilizadas en un soporte modelo en la hidrolisis enzimática de celulosa sometida a pre tratamientos hidrotérmicos.

\section{Materiales y método}

El pretratamiento hidrotérmico de la celulosa se realizó siguiendo la metodología propuesta por Nitsos et al (Nitsos et al., 2013), en la cual se colocó celulosa micro cristalina (C6429 de Sigma-Aldrich) en presencia de agua destilada en una proporción de 1:15 en un reactor de acero inoxidable totalmente sellado a distintas condiciones de temperatura y tiempo con una agitación constante de $700 \mathrm{rpm}$. Las condiciones de temperatura y tiempo se calcularon según el factor de severidad (log $\left.\left(R_{0}\right)\right)$, según la ecuación:

$$
\mathrm{R}_{0}=\mathrm{t} \exp [(\mathrm{T}-100) / 14.75]
$$

Donde: $\mathrm{R}_{0}=$ factor de severidad, $\mathrm{T}=$ temperatura en ${ }^{\circ} \mathrm{C}, \mathrm{t}=$ tiempo en $\min$ [35]. 
Se plantearon siete tratamientos hidrotérmicos, tal como se muestra en la tabla 1.

Tabla 1. Relación de tiempo y temperaturas según el factor de severidad estudiado

\begin{tabular}{ccc}
\hline Tiempo (min) & $\begin{array}{c}\text { Temperatura } \\
\left({ }^{\circ}\right)\end{array}$ & log $\left(\mathrm{R}_{0}\right)$ \\
\hline 60 & 90 & 1,48 \\
60 & 110 & 2,07 \\
60 & 130 & 2,66 \\
60 & 150 & 3,25 \\
120 & 150 & 3,55 \\
180 & 150 & 3,72 \\
240 & 150 & 3,85 \\
\hline
\end{tabular}

Después del tiempo de reacción, el producto (sobrenadante y la celulosa pretratada) se centrifugo a $4000 \mathrm{rpm}$ por 10 minuto. El sobrenadante se recolecto en tubos de ensayo y se le realizó la evaluación de azucares reductores según el método de (Miller 1959) (Miller, 1959); la fracción solida se secó en un rotaevaporador hasta que la muestra quedo totalmente seca y se analizó por espectroscopia infrarroja con transformada de Fourier (FTIR) en un FTIR Nicolet IS50 en modalidad de absorbancia con pastillas de $\mathrm{KBr}$.

Para los estudios de inmovilización de celulasas, se inmovilizó Celulasa de Trichoderma reesei (ATCC 26921 C2730 (EC 3.2.1.4.), Sigma-Aldrich de $\geq 700$ units/g) en un soporte de $\mathrm{SiO}_{2}-\mathrm{NH}_{2}$, preparado previamente usando $\mathrm{SiO}_{2}$ comercial (Syloid 266 de Grace Davidson) funcionalizado con aminopropiltrietoxisilano (APTES $>99 \%$, Sigma Aldrich). El procedimiento de inmovilización se realizó disolviendo la celulasa (EC 3.2.1.4.) en un buffer fosfato de sodio manteniendo el pH en 7, a la cual se le adicionó una proporción de 1:10 de enzima: soporte, posteriormente se agitó por 18 horas a $4{ }^{\circ} \mathrm{C}$. Después de transcurrido la 18 horas de agitación, la celulasa inmovilizada se centrifugo a $4000 \mathrm{rpm}$ durante 15 minutos, el primer sobrenadante resultado de la inmovilización se tomó como la enzima residual y se determinó la cantidad de proteína residual por el método de Lowry, 1951 (Lowry, Rosebrough, Farr, \& Randall, 1951). Posteriormente se realizó 10 lavados con agua destilada a la celulasa inmovilizada en el soporte modelo a $4000 \mathrm{rpm}$ durante dos minutos luego se resuspendió la enzima inmovilizada en buffer citrato $\mathrm{pH} 4.8$. La evaluación de la actividad enzimática de la celulasa libre e inmovilizada se realizó mediante el ensayo de papel filtro según el protocolo de Ghose (1987) (Goshe.T.K, 1987) en buffer citrato $\mathrm{pH} 4.8$ y posteriormente se estudió la hidrolisis enzimática 
de los mejores pretratamientos hidrotérmicos usando $41 \mathrm{mg}$ de la celulosa pre tratada en vez de papel filtro. La cantidad de glucosa liberada por la dilución de celulasa libre y celulasa inmovilizada se reporta como las cantidades de glucosa (FPU) liberados según la ecuación:

$\mathrm{FPU}=\mathrm{mg}$ glucosa liberado $\times 0,185$.

Donde 0,185 es una constante que indica que un $1 \mathrm{mg}$ de glucosa $=1.0 / 0,18 \mathrm{x}$

$0,5 \times 60 \mu \mathrm{mol} \mathrm{min}^{-1} \mathrm{~mL}^{-1}$ de sustrato. (Goshe.T.K, 1987)

\section{Resultados y discusión}

\subsection{Selección de las condiciones de tratamiento hidrotérmico}

En la primera etapa del estudio se seleccionó los mejores pretratamientos teniendo en cuenta el índice de cristalinidad (IC) y concentración de azucares reductores. La tabla 2 relaciona el factor de severidad (Log $\mathrm{R}_{0}$ ) y el índice de cristalinidad (IC) de la celulosa pretratada y el contenido de azúcares reductores presentes en el sobrenadante de los tratamientos hidrotermicos. El factor de severidad se ha usado para permitir una fácil comparación de los resultados y determinar los parámetros experimentales necesarios para disminuir el grado de cristalinidad de la celulosa, en relación con la capacidad de ruptura de polisacáridos según la proporción temperatura y tiempo (Nitsos et al., 2013) .

El IC fue calculado a partir de la relación de absorbancia de la señal a $\sim 1431 \mathrm{~cm}^{-1}$ y la señal $\sim 900 \mathrm{~cm}^{-1}$ de los espectros de FTIR obtenidos para cada una de los tratamientos de celulosa tratada hidrotermicamente. La señal a $1431 \mathrm{~cm}^{-1}$ se designa como la "celulosa cristalina" y la señal a $900 \mathrm{~cm}^{-1}$ se designa como celulosa amorfa (Sang Youn Oh, Dong IlYoo, Younsook Shin, \& Gon Seo, 2005). Las intensidades de absorbancia a 900 y $1430 \mathrm{~cm}^{-1}$ son muy sensibles a la cantidad de estructura cristalina frente a la estructura amorfa de la celulosa, es decir, la ampliación de la banda de $900 \mathrm{~cm}^{-1}$ refleja una mayor cantidad de estructura desordenada. La presencia de estas señales depende del tratamiento efectuado.

Puede observarse en la tabla 2, que el índice de cristalinidad es bruscamente afectado por un cambio menor en el grado de severidad, pero a partir de un grado de severidad mayor ( $\log \mathrm{R}_{0}=2,5$ ) el IC permanece constante, lo que indica que a pesar que se incremente el factor de severidad para realizar el pretratamiento hidrotérmico el índice de cristalinidad no presentará una mayor disminución.

Con respecto a la concentración de glucosa $(\mathrm{mg} / \mathrm{mL})$ presente en los sobrenadantes, los resultados indican que aumenta proporcionalmente con respecto al factor de 
47

severidad, y toma una forma asintótica a mayores valores de Log $R_{0}$ (véase Figura 1).

Tabla 2. Factor de severidad (Log $\mathrm{R}_{0}$ ) y su correspondiente índice de cristalinidad (IC) de la celulosa pretratada hidrotermicamente y concentración de glucosa presente en cada uno de los sobrenadantes.

\begin{tabular}{ccc}
\hline Log $\mathbf{R}_{\mathbf{0}}$ & $\begin{array}{c}\text { IC presente en la } \\
\text { celulosa pretratada }\end{array}$ & $\begin{array}{c}\mathbf{m g} \mathbf{m L} \text { de glucosa } \\
\text { presente en los } \\
\text { sobrenadantes }\end{array}$ \\
0 & 1,62 & - \\
1,5 & 1,62 & 0,21 \\
2,5 & 1,31 & 0,21 \\
2,7 & 1,23 & 0,22 \\
3,3 & 1,22 & 0,24 \\
3,6 & 1,26 & 0,25 \\
3,7 & 1,24 & 0,28 \\
3,9 & 1,21 & 0,40 \\
\hline
\end{tabular}

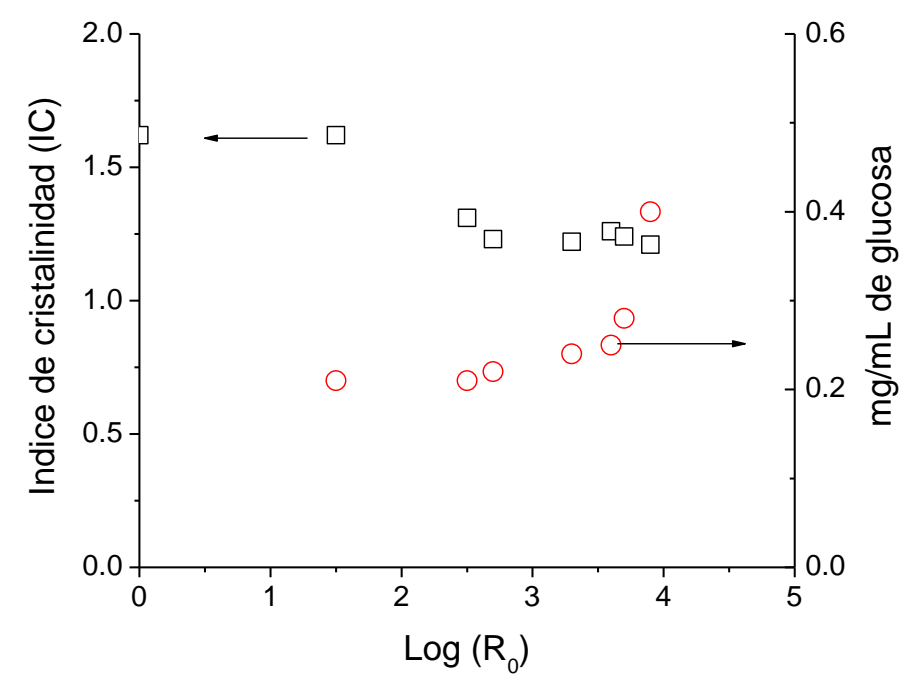

Figura 1. Factor de severidad ( $\log \mathrm{R}_{0}$ ) y su correspondiente índice de cristalinidad (IC) de la celulosa pretratada hidrotermicamente y cconcentración de glucosa presente en cada uno de los sobrenadantes. 
Teniendo en cuenta los resultados descritos anteriormente se podrían clasificar tres regiones en un tratamiento hidrotérmico, una región inicial donde no se modifica el IC ni la concentración de azúcares reductores, una región intermedia donde el IC cae bruscamente pero la concentración de azúcares reductores no se modifica y una tercera región donde el IC no se disminuye más pero aumenta la concentración de azúcares reductores. Estas tres regiones se pueden explicar considerando que solo valores de Log $R_{0}$ superior a 3,0 se podría modificar la estructura cristalina de la celulosa y que mayores valores de Log $R_{0}$ reflejarían una degradación de la celulosa amorfa más que de la celulosa cristalina, explicando así el valor más alto de los azúcares reductores cuando el IC es superior a 3.0. Sobre estas regiones se estudió la degradación enzimática.

\subsection{Inmovilización de celulasas Trichoderma ressei ATCC 26921}

El método empleado para la inmovilización de la celulasa ha sido la unión mediante interacciones electroestáticas entre la enzima y la sílice aminada. El pH de inmovilización presenta un valor intermedio entre el punto isoeléctrico del soporte y el de la enzima ( $\mathrm{pI}$ 6.0). En los materiales puramente silíceos $(\mathrm{pI}=2,0)$ la región de trabajo, es relativamente estrecha y es muy difícil su inmovilización, la diferencia de cargas, no es muy grande, por lo que se establecen bajas interacciones electrostáticas, y como resultado la carga enzimática, la actividad y eficiencia catalítica de los biocatalizadores son bajas. Al funcionalizar con grupos aminopropilo, la superficie incrementa el punto isoeléctrico del soporte y mejora la afinidad por la enzima. La funcionalización con grupos amino (pKa 10,5) permite realizar la inmovilización a valores de $\mathrm{pH}$ mucho más alejados de los puntos isoeléctricos de enzima y soporte, potenciando las atracciones electrostáticas. Cuando el $\mathrm{pH}$ de inmovilización es de 7,0 los grupos amino del soporte están cargados positivamente y la enzima negativamente. Por esta razón se escogió este $\mathrm{pH}$ para la inmovilización, lo que permitiría una mayor afinidad química de la enzima por la superficie de los materiales. Los resultados de la proteína acoplada mostraron que la eficiencia de la unión soporte-enzima de la sílice aminada $\left(\mathrm{SiO}_{2}-\mathrm{NH}_{2}\right)$ con la celulasa presenta un rendimiento de inmovilización relativamente alto cerca al $88 \%$ de la celulasa inicialmente cargada como se evidencia en la tabla 3. La eficiencia de unión de la proteína acoplada, se debe al área de superficie del soporte $\mathrm{SiO}_{2}-\mathrm{NH}_{2}\left(202 \mathrm{~cm}^{2} / \mathrm{g}\right)$ y al pH de la inmovilización utilizado. 
Tabla 3. Concentración de proteína dilución celulasa libre, proteína residual, dilución de celulasa libre / $1 \mathrm{~mL}$ buffer, proteína residual / 1mL buffer, proteína acoplada / 1 $\mathrm{mL}$ de buffer, proteína acoplada / $1 \mathrm{~mL}$ buffer*mg soporte y porcentaje de proteína acoplada

\begin{tabular}{lc}
\hline \multicolumn{1}{c}{ Proteína } \\
\hline Proteína dilución celulasa libre $(\mathrm{mg} / \mathrm{mL}) / 1 \mathrm{~mL}$ buffer \\
Proteína Residual $(\mathrm{mg} / \mathrm{mL}) / 1 \mathrm{~mL}$ buffer & 0,0462 \\
Proteína acoplada $(\mathrm{mg} / \mathrm{mL}) / 1 \mathrm{~mL}$ buffer & 0,0054 \\
Proteína acoplada $(\mathrm{mg} / \mathrm{mL}) / 1 \mathrm{~mL}$ buffer $* \mathrm{mg}$ de soporte & 0,0408 \\
Porcentaje $(\%)$ de proteína acoplada $(\mathrm{mg} / \mathrm{mL}) / 1 \mathrm{~mL}$ & 88 \\
buffer & \\
\hline
\end{tabular}

La tabla 4 resume la actividad expresada en FPU de las células libres e inmovilizadas utilizando celulosa cristalina y celulosa tratada hidrotermicamente. Una menor actividad de la enzima inmovilizada es observada comparada con la enzima libre. El $80 \%$ de la actividad de la enzima se retiene con celulosa cristalina, mientras un 50 $\%$ con celulosa tratada hidrotermicamente. Estos resultados se pueden observar mejor en la Figura 2, donde se observa una menor disminución de la eficiencia de la actividad enzimática de la dilución de enzima libre con respecto a la celulosa inmovilizada. En todo caso, el tratamiento hidrotérmico favorece la actividad de la enzima, puesto que a mayor factor de severidad mayor actividad enzimática, lo que indica que al exponer la celulosa a un pretratamiento térmico la estructura cristalina se disocia para que posteriormente la celulasa pueda actuar de manera eficiente y se obtenga una mayor producción de azucares reductores. Por lo tanto se evidencia que el pretratamiento hidrotérmico causa cambios estructurales a la celulosa y tiene un impacto significativo en la producción de azúcares reductores $(\mathrm{Pu}, \mathrm{Hu}$, Huang, Davison, \& Ragauskas, 2013).

Tabla 4. Actividad enzimática de la dilución de celulasa libre y celulasa inmovilizada con celulosa cristalina y los pretratamientos (FPU unit/mL)

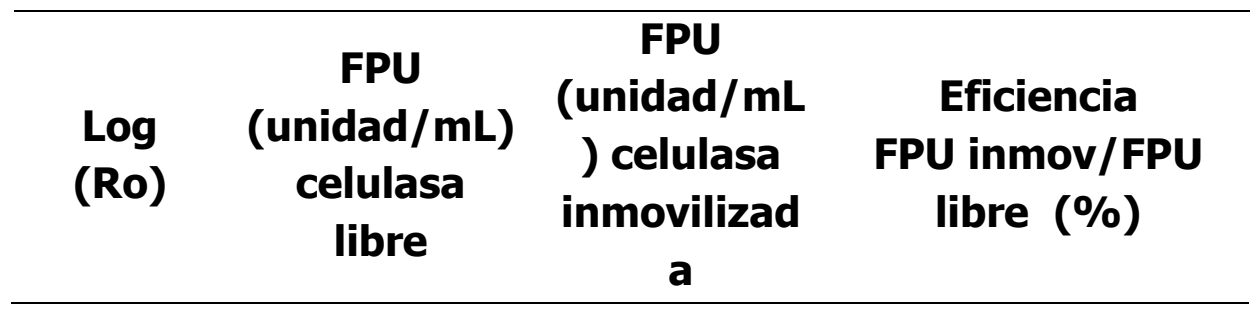




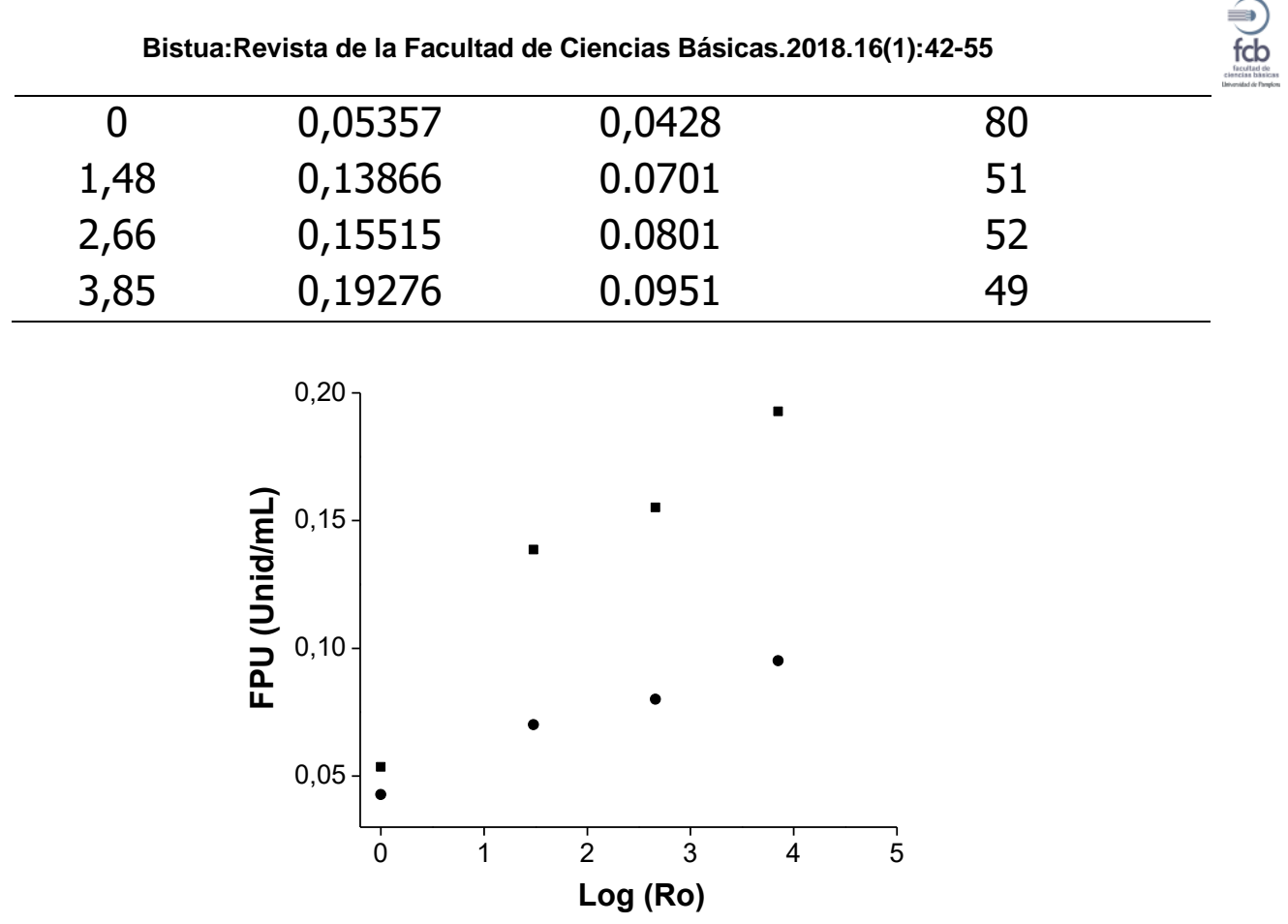

Figura 2. Log (Ro) Vs. Actividad enzimática de dilución celulasa libre (•) y celulasa inmovilizada $(\bullet$ ) en FPU (Unid/mL)

\section{Conclusiones}

El tratamiento hidrotérmico incrementó de manera significativa la degradación enzimática, observándose una mayor actividad enzimática a mayores valores de log $\left(R_{0}\right)$. A partir de un log $\left(R_{0}\right)$ de 2,66 el índice de cristalinidad no se modificó sugiriendo que a mayores valores de log $\left(R_{0}\right)$ solo se transformará la celulosa amorfa. Se sintetizó un soporte $\left(\mathrm{SiO}_{2}-\mathrm{NH}_{2}\right)$ que logra por métodos de adsorción física retener más del $80 \%$ de la enzima inmovilizada. Aunque se presentó una disminución en la actividad enzimática de las celulasas inmovilizadas cercana al 50 $\%$, se evidencia que el tratamiento hidrotérmico favorece la hidrolisis de la celulosa.

\section{Agradecimientos}

Los autores agradecen a Colciencias por el soporte financiero bajo el Proyecto No. 110965843004.

\section{Referencias Bibliograficas}

Balat, M. (2011). Production of bioethanol from lignocellulosic materials via the biochemical pathway: A review. Energy Conversion and Management, 52 (2), 858875. 
Chaparro, S. P., Lara, A. E., Sandoval, A., Sosa, S. J., Martínez, J. J., \& Gil González, J. H. (2015). Functional Characterization of Mango Seeds Kernel (Mangifera indica L.). Ciencia En Desarrollo, 6(1), 67-75.

Dinjus, E., \& Kruse, A. (2004). Hot compressed water-a suitable and sustainable solvent and reaction medium? Journal of Physics: Condensed Matter, 16, S1161S1169.

Goshe.T.K. (1987). Measurement of cellulase activities. Applied Chemistry Division Commission on Biotechnology, 59 (5), 695-702.

Huang, F., \& Ragauskas, A. J. (2012). Dilute $\mathrm{H}_{2} \mathrm{SO}_{4}$ and $\mathrm{SO}_{2}$ pretreatments of Loblolly pine wood residue for bioethanol production. Ind Biotechnol, 8 (1): 22-30.

Juturu, V., \& Chuan, J. (2014). Microbial cellulases: Engineering, production and applications. Renewable and Sustainable Energy Reviews, 33, 188-203.

Li, H., Pu, Y., Kumar, R., Ragauskas, A. J., \& Wyman, C. E. (2012). Investigation of lignin deposition on cellulose during hydrothermal pretreatment, its effect on cellulose hydrolysis, and underlying mechanisms. Sheraton, New Orleans: 34th Symposium on Biotechnology for Fuels and Chemicals.

Lowry, O., Rosebrough, J., Farr, L., \& Randall, R. . (1951). Protein measurement with the Folin phenol reagent. The Journal of Biological Chemistry, 193 (1), 265275.

Miller, G. L. (1959). Use of Dinitrosalicylic Acid Reagent for Determination of Reducing Sugar. Analytical Chemistry, 31(3), 426-428.

Moreno, L. M., Muñoz Prieto, E., \& Casanova, H. (2015). Flocculation with Chitosan of Microalgae Native of the Colombian Plateau Floculación con quitosano de las microalgas nativas de la altillanura Colombiana. Ciencia En Desarrollo, 6(1), 25-31.

Muñoz Prieto, E., Rivas, B., \& Sánchez, J. (2013). Natural polymer grafted with synthetsic monomer by microwave for water treatment: A review. Ciencia En Desarrollo, 4, 219-240.

Nickerson, R. F., \& Habrle, J. A. (1947). Cellulose intercrystalline structure: study by 
hydrolytic methods. Ind Eng Chem Res, 39 (11), 1507-1512.

Nitsos, C. K., Matis, K. A., \& Triantafyllidis, K. S. (2013). Optimization of Hydrothermal Pretreatment of Lignocellulosic Biomass in the Bioethanol Production Process. ChemSusChem, 6(1), 110-122.

Pu, Y., Hu, F., Huang, F., Davison, B. H., \& Ragauskas, A. J. (2013). Assessing the molecular structure basis for biomass recalcitrance during dilute acid and hydrothermal pretreatments. Biotechnology for Biofuels, 6(1), 15.

Rojas, H. A., Martínez, J. J., \& Vargas, A. Y. (2014). Selección de soportes magnéticos para la inmovilización de Ureasa. Ingeniería Y Competitividad, 296 (2), 289-296.

Sang Youn Oh, Dong IIYoo, Younsook Shin, \& Gon Seo. (2005). FTIR analysis of cellulose treated with sodium hydroxide and carbon dioxide. Carbohydrate Research, 340(3), 417-428.

Sun, Y., \& Jiayang, C. (2002). Hydrolysis of lignocellulosic materials for ethanol production: a review. Bioresource Technology, 83(1), 1-11.

Xiong, H., Pham, H. N., \& Datye, A. K. (2014). Hydrothermally stable heterogeneous catalysts for conversion of biorenewables. Green Chemistry, 16(11), 4627-4643.

Zheng, Y., Zhao, J., Fuqing, X., \& Yebo, L. (2014). Pretreatment of lignocellulosic biomass for enhanced biogas production. Progress in Energy and Combustion Science, 42, 35-53. 
TABLAS

Tabla 1. Relación de tiempo y temperaturas según el factor de severidad estudiado

\begin{tabular}{ccc}
\hline Tiempo $(\min )$ & Temperatura $\left(^{\circ}\right)$ & $\log \left(\mathrm{R}_{0}\right)$ \\
\hline 60 & 90 & 1,48 \\
60 & 110 & 2,07 \\
60 & 130 & 2,66 \\
60 & 150 & 3,25 \\
120 & 150 & 3,55 \\
180 & 150 & 3,72 \\
240 & 150 & 3,85 \\
\hline
\end{tabular}

Tabla 2. Factor de severidad ( $\log \mathrm{R}_{0}$ ) y su correspondiente índice de cristalinidad (IC) de la celulosa pretratada hidrotermicamente y concentración de glucosa presente en cada uno de los sobrenadantes.

\begin{tabular}{ccc}
\hline Log Ro & $\begin{array}{c}\text { IC presente en la celulosa } \\
\text { pretratada }\end{array}$ & $\begin{array}{c}\mathbf{m g} / \mathbf{m L} \text { de glucosa presente } \\
\text { en los sobrenadantes }\end{array}$ \\
0 & 1,62 & - \\
1,5 & 1,62 & 0,21 \\
2,5 & 1,31 & 0,21 \\
2,7 & 1,23 & 0,22 \\
3,3 & 1,22 & 0,24 \\
3,6 & 1,26 & 0,25 \\
3,7 & 1,24 & 0,28 \\
3,9 & 1,21 & 0,40 \\
\hline
\end{tabular}

Tabla 3. Concentración de proteína dilución celulasa libre, proteína residual, dilución de celulasa libre / $1 \mathrm{~mL}$ buffer, proteína residual / 1mL buffer, proteína acoplada / $1 \mathrm{~mL}$ de buffer, proteína acoplada / $1 \mathrm{~mL}$ buffer*mg soporte y porcentaje de proteína acoplada

\begin{tabular}{lc}
\hline \multicolumn{2}{c}{ Proteína } \\
\hline Proteína dilución celulasa libre $(\mathrm{mg} / \mathrm{mL}) / 1 \mathrm{~mL}$ buffer \\
Proteína Residual $(\mathrm{mg} / \mathrm{mL}) / 1 \mathrm{~mL}$ buffer & 0,0462 \\
Proteína acoplada $(\mathrm{mg} / \mathrm{mL}) / 1 \mathrm{~mL}$ buffer & 0,0054 \\
Proteína acoplada $(\mathrm{mg} / \mathrm{mL}) / 1 \mathrm{~mL}$ buffer $* \mathrm{mg}$ de soporte & 0,0408 \\
Porcentaje $(\%)$ de proteína acoplada $(\mathrm{mg} / \mathrm{mL}) / 1 \mathrm{~mL}$ buffer & 0,00041 \\
\hline
\end{tabular}


54

Tabla 4. Actividad enzimática de la dilución de celulasa libre y celulasa inmovilizada con celulosa cristalina y los pretratamientos (FPU unit/mL)

\begin{tabular}{cccc}
\hline Log (Ro) & $\begin{array}{c}\text { FPU } \\
\text { (unidad/mL) } \\
\text { celulasa libre }\end{array}$ & $\begin{array}{c}\text { FPU } \\
\text { (unidad/mL) } \\
\text { celulasa } \\
\text { inmovilizada }\end{array}$ & $\begin{array}{c}\text { Eficiencia } \\
\text { FPU inmov/FPU libre } \\
\mathbf{( \% )}\end{array}$ \\
\hline 0 & 0,05357 & 0,0428 & 80 \\
1,48 & 0,13866 & 0.0701 & 51 \\
2,66 & 0,15515 & 0.0801 & 52 \\
3,85 & 0,19276 & 0.0951 & 49 \\
\hline
\end{tabular}

\section{FIGURAS}

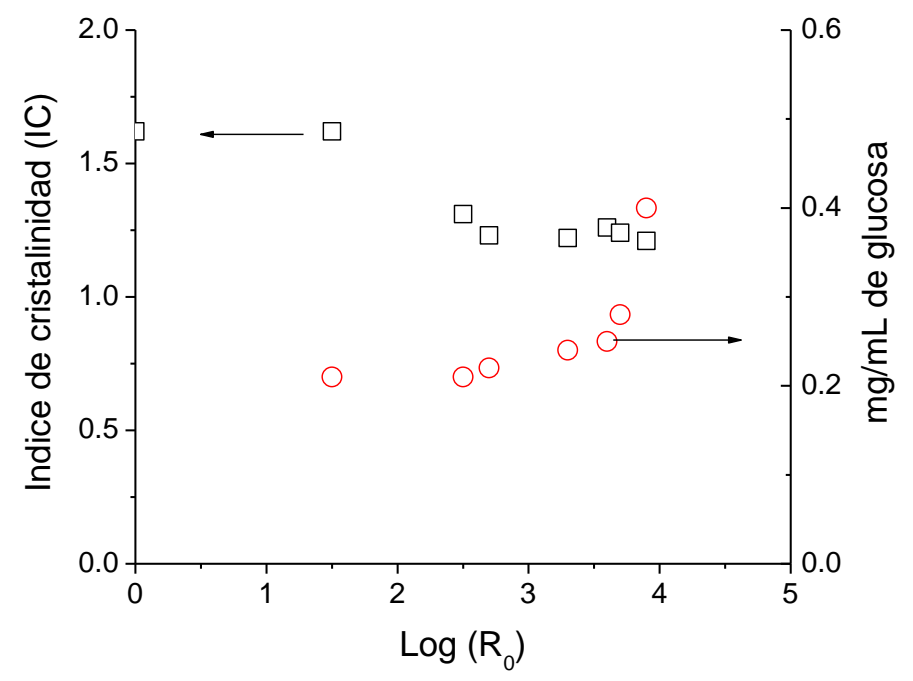

Figura 1. Factor de severidad ( $\log R_{0}$ ) y su correspondiente índice de cristalinidad (IC) de la celulosa pretratada hidrotermicamente y cconcentración de glucosa presente en cada uno de los sobrenadantes. 


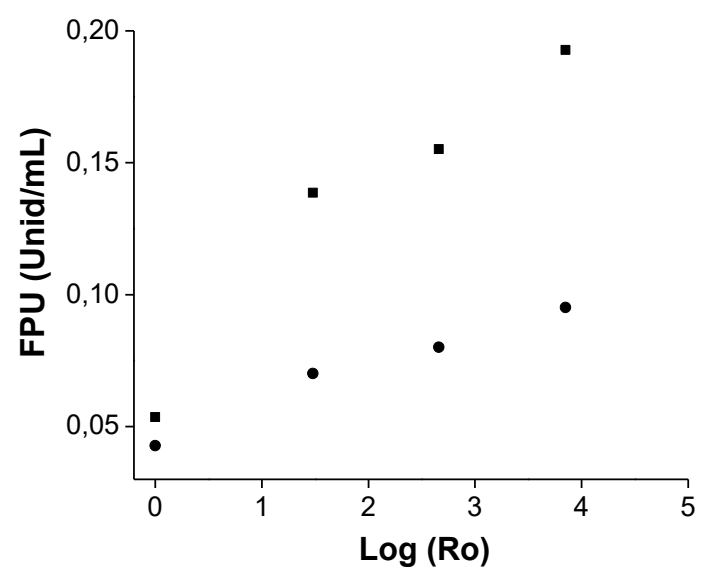

Figura 2. Log (Ro) Vs. Actividad enzimática de dilución celulasa libre $(\cdot)$ y celulasa inmovilizada $(\bullet$ ) en FPU (Unid/mL)

*Para citar este artículo: Vargas A.Y.; Luque L.;Martinez J.J .Study of hydrothermal pretreatment to increase the activity of free and immobilized cellulases. Revista Bistua.2018.16(1):42-55

+ Autor para el envió de correspondencia y la solicitud de las separatas: Martinez J.J. . Escuela de Ciencias Químicas. Facultad de Ciencias. Universidad Pedagógica y Tecnológica de Colombia.Tunja, Boyacá, Colombia. jose.martinez@uptc.edu.co

Recibido: Noviembre 20 de 2016

Aceptado: Enero 10 de 2018 